\title{
History of The Research on Sex Determination
}

\author{
Jacek Z Kubiak ${ }^{1,2}$, Malgorzata Kloc $^{3-5}$ and Rafal P Piprek ${ }^{6 *}$ \\ ${ }^{1}$ UnivRennes, CNRS, UMR 6290, IGDR, Cell Cycle Group, F-35000 Rennes, France \\ ${ }^{2}$ Military Institute of Hygiene and Epidemiology, ZMRiBK, Warsaw, Poland \\ ${ }^{3}$ The Houston Methodist Research Institute, USA
}

${ }^{4}$ Department of Surgery, The Houston Methodist Hospital, USA

${ }^{5}$ University of Texas, MD Anderson Cancer Center, USA

${ }^{6}$ Department of Comparative Anatomy, Institute of Zoology and Biomedical Research, Jagiellonian University, Poland

*Corresponding author: Rafał P Piprek, Department of Comparative Anatomy, Institute of Zoology and Biomedical Research,

Jagiellonian University, Poland

\begin{tabular}{|c|c|}
\hline ARTICLE INFO & ABSTRACT \\
\hline 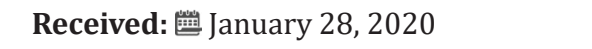 & \multirow{3}{*}{$\begin{array}{l}\text { Since the beginning of the humanity, people were fascinated by sex and intrigued by } \\
\text { how the differences between sexes are determined. Ancient philosophers and middle } \\
\text { age scholars proposed numerous fantastic explanations for the origin of sex differences } \\
\text { in people and animals. However, only the development of the modern scientific methods } \\
\text { allowed us to find, on the scientific ground, the right answers to these questions. In this } \\
\text { review article, we describe the history of these discoveries, and which major discoveries } \\
\text { allowed the understanding of the origin of sex and molecular and cellular basis of the } \\
\text { differentiation of male and female sex characteristics during embryo development and } \\
\text { in the adult. }\end{array}$} \\
\hline Published: 幽 February 06, 2020 & \\
\hline $\begin{array}{l}\text { Citation: Jacek Z Kubiak, Malgorzata Kloc, } \\
\text { Rafal P Piprek. History of The Research on } \\
\text { Sex Determination. Biomed J Sci \& Tech Res } \\
\text { 25(3)-2020. BJSTR. MS.ID.004194. }\end{array}$ & \\
\hline $\begin{array}{l}\text { Keywords: Sex Determination; Sexual } \\
\text { Development; Gonad Development; Sex } \\
\text { Hormones }\end{array}$ & $\begin{array}{l}\text { Abbreviations: TDF: Testis-Determining Factor; ZFY: Zinc-Finger Protein Y-Linked; } \\
\text { BKM: Banded Krait Minor Gene; AMH: Anti-Müllerian hormone; TSD: Temperature Sex } \\
\text { Determination; DHT: Dihydrotestosterone }\end{array}$ \\
\hline
\end{tabular}

\section{Introduction}

\section{The First Concepts of Sex Determination}

In the multicellular organisms, sex is a set of features of the structure, function, and behavior of the body that allows it to be classified as a male or female individual. Sex determination is directly linked to the determination of the direction of the development of yet undifferentiated gonads into the testes or ovaries. The sexual characteristics of the individual are formed during the process of sexual differentiation. For sexually reproducing multicellular organisms, the correct structure and function of the reproductive system is a prerequisite for having a healthy and fertile offspring, which is the basis of maintaining the continuity of the species. The emergence of sex turned out to be a significant advancement in evolution, as the merger of the male and female gametes, resulting from the existence of sex, provided a high degree of genetic variability of the offspring.
Thus, in contrast to the asexually reproducing organisms, the population of sexually reproducing organisms became more diverse, and as a result, more easily adaptable to the changing environment. For centuries, humanity has been intrigued by the nature of sex, the sense of its existence and origin. The issue of sex already appeared in the book of Genesis (2: 21-24), which tells about the creation by God of the man (Adam) and the women from Adam's rib. Plato, in his work entitled "Symposium", written around 385-370 BC, presented his vision of the origin of human sex. In this work, Aristophanes talks about primitive people with round shapes, two pairs of arms and legs, and two faces. These people had exerted an extraordinary fear even among the gods. The god Zeus, to guard against these strong creatures, decided to cut them in half. This is how men and women were created. Both halves began to miss each other, showing the need for unity expressed in the form 
of love. In this way, Plato explained the essence of sex inseparable from the feeling of love.

One of the most mysterious issues remaining for centuries was what determines the sex of the individual, and thus how the sex is determined. The Greek philosopher Parmenides (540-470 $\mathrm{BC}$ ) claimed that the sex of a child is determined by the position of the fetus in the womb. Male development would be determined by the position of the fetus on the right side of the womb and the female on the left. Around 500-428 BC, another Greek philosopher Anaxagoras recognized that it is the paternal factor that determines the sex of the child; namely, the boys develop from the sperm from the right testicle and the girls from the left testicle. Then, Empedocles (494-434 BC) claimed that organisms consist of four elements: fire (heat), water (cold), air (moisture) and earth (dryness), and that the men have a more warm ingredient [1]. The most outstanding biologist of the antiquity - Aristotle (384-322 BC) did not agree with the statements of the above-mentioned thinkers. He believed that he had evidence that the female and male offspring could develop on both sides of the womb (uterus) and noted that the men with only one testicle could conceive both male and female offspring $[2,3]$. Similar to Empedocles, Aristotle saw the mechanisms of sex determination as the predominance of hot or cold ingredients in the body [1]. In his work, "Historia Animalium", he pointed out that males are stronger, which is due to their higher heat, enabling the transformation of food into the concentrated seed. Females, on the other hand, in Aristotle's opinion, were weaker and cooler, which meant that they could not convert food into sperm, and instead produced more blood that is excreted during menstruation. According to Aristotle, the development of fetus sex was dependent on the connection of sperm with menstrual blood during conception. Sperm thickening due to the heat was to lead to the development of the male individual, while liquefaction of the sperm at a lower temperature, leading to its mixing with the mother's blood, resulted in the development of the female individual. He also stated that both man and woman (through semen and blood) contribute to the offspring, and thought, which turned out to be true, that male and female organs develop during development from undifferentiated buds. Importantly, he stated that the testes are responsible for the development of male traits, i.e. masculinization since the testisdeprived eunuchs show feminization features [2]. Thus, among the ancient thinkers, it was Aristotle who was closest to the truth, and his observations did indeed contribute to the broadening of knowledge about gender determination.

\section{First Scientific Evidence of Sex Determination}

The belief that the heat, positioning of the fetus in the womb and food determine sex, nestled in peoples' minds for a long time, and survived for nearly two thousand years [3]. In the second half of the nineteenth century, it was believed that heat and nutrition affect a child's sex [4]. This faith resounds even today in folk beliefs. The milestone in the biological research was the discovery of chromosomes in 1888 by the German anatomist, physiologist and pathologist Heinrich Waldeyer (Figure 1) [5]. Already three years later, in 1891, the German cytologist Hermann Henking, studying the meiotic division in the nuclei of a wingless blacksmith (Hemiptera), noticed that some sperm cells of this species have 12 chromosomes, and some 11 . He noticed that, during meiosis, one of the 12 chromosomes behaves differently than others. By naming this strange chromosome the $\mathrm{X}$ chromosome, he wanted to emphasize its mysterious nature [6,7]. He then searched for the X chromosome in the grasshopper cells, but to no avail [6]. It wasn't until 1901 that American zoologist Clarence Erwin McClung pointed out that the X chromosome, as an "additional chromosome," could be associated with sex determination [8].

In 1905, American geneticist Edmund Beecher Wilson, studying spermatogenesis of several insect species, showed that there are two types of sperm, which differ in the presence or absence of one of the chromosomes (Figure 1) [9]. In the same year, the American geneticist Nettie Maria Stevens, studying the gametogenesis of the mealworm beetle, found that in males, but not females, one chromosome was significantly different in size [10]. Therefore, Stevens stated that the larger chromosome is the $\mathrm{X}$ chromosome, while the smaller chromosome, which she called Y, must be responsible for male determination [10]. She also suggested that there must be some unknown factor in the $Y$ chromosome that determines male development. Wilson, on the other hand, believed that both chromosomes, X and Y, determine sex equally [11]. Stevens died in 1912 without confirming her hypothesis, and Wilson has been described in scientific literature as a discoverer of sex-determining $\mathrm{X}$ and $\mathrm{Y}$ chromosomes [11]. Description of sex chromosomes contributed to the statement that sex is determined by genes. Around the same period (early $20^{\text {th }}$ century), chromosomes were found to carry genetic information. Walter Sutton and Theodor Boveri discovered this, independently, in 1903 (Figure 1) [12]. The term "gene" was introduced in 1909 by the Danish botanist Wilhelm Johannsen. However, in 1910, the American geneticist Thomas Hunt Morgan, studying the inheritance of features in the fruit fly, showed that the genes are located in the chromosomes where they are linearly arranged, and occupy strictly defined places, the so-called loci [13]. In addition, he showed that some features (e.g. eye color) are sex-linked because their genes are located in the sex chromosomes [14]. Interestingly, the understanding of the basics of inheritance mechanisms was possible at the beginning of the $20^{\text {th }}$ century, again, thanks to the research on insects. Nevertheless, the mechanism by which sex chromosomes determine sex was to remain unexplained for a long time. Only a few decades later, in 1956, in the Great Britain, Charles Ford and John Hamerton, using cytogenetic methods, determined the number of chromosomes in humans and found that men have X and Y chromosomes (karyotype 46, XY), and women two chromosomes X (karyotype 46, XX) (Figure 1) [15]. Three years after this discovery, the first chromosomal aberrations in 
humans were described. It was noticed that people with Klinefelter syndrome are men with 47, XXY karyotype [16], while people with Turner syndrome are women with 45 , X0 karyotype [17]. This was the first scientific evidence confirming that the Y chromosome in humans determines the male sex.

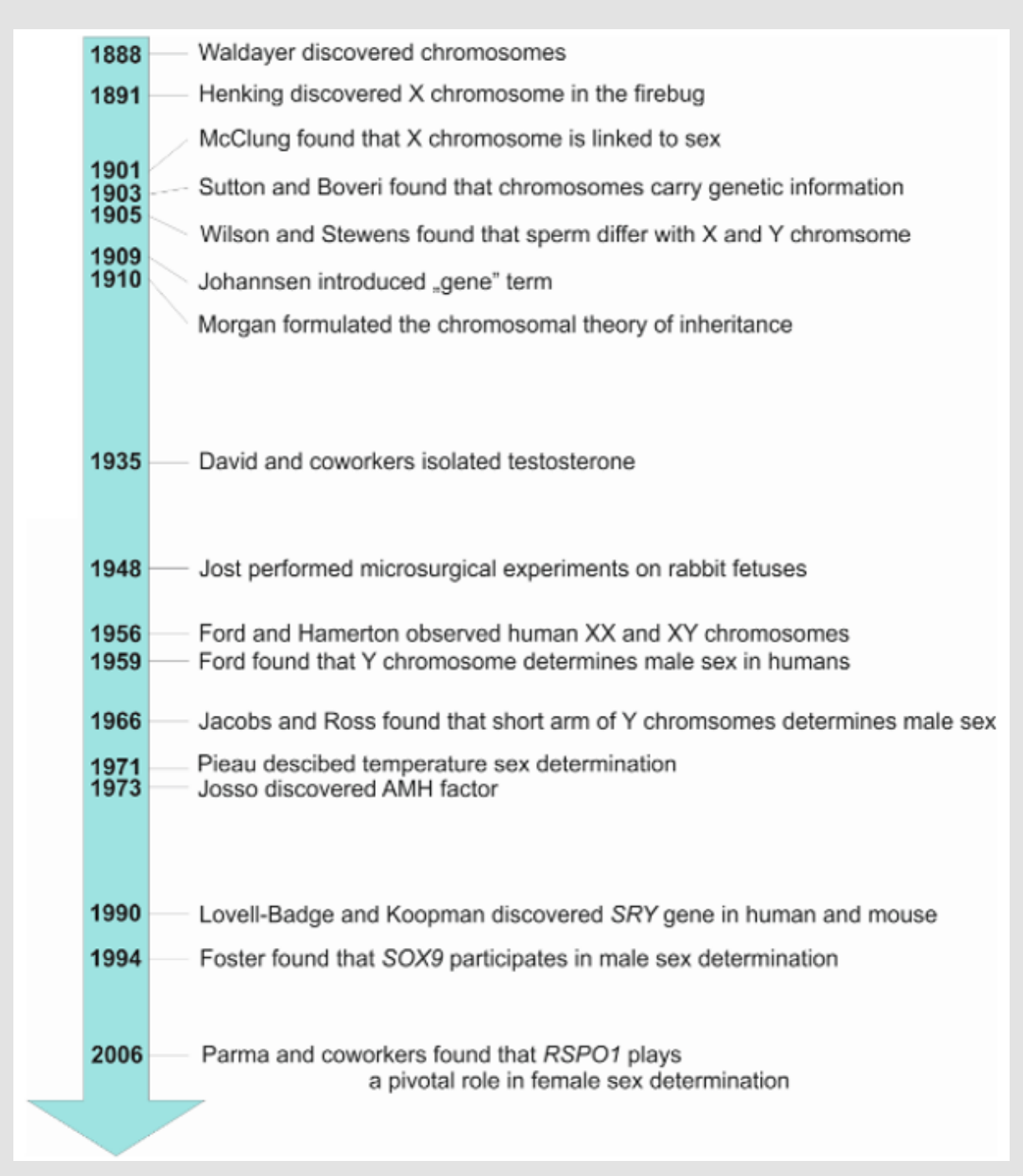

Figure 1: Chronology of principal discoveries in the studies of sex determination.

\section{Searching for the Factor Determining Male Sex}

The discovery of the function of the $\mathrm{Y}$ chromosome in the determination of the male sex in humans initiated the search for a hypothetical factor determining this particular sex. This hypothetical factor was named TDF (Testis-Determining Factor) in humans, and Tdy (testis-determining factor on the Y chromosome) in mice. At that time, the most informative objects of research on sex determination were patients with sex reversal symptoms, i.e. incompatibilities between the presence of sex chromosomes and phenotypic features. The analyzes of chromosomal aberrations, such as translocations and fusions, indicated that it is the short arm of the $\mathrm{Y}$ chromosome that is responsible for male determination [18]. Also, the search area for the TDF factor has been gradually narrowing. Among the genes of the smaller arm of the $Y$ chromosome, the first candidates were the H-Y antigen and BKM genes (Banded Krait Minor Gene), but their involvement in sex determination has not been demonstrated [3]. The next gene tested was ZFY (Zinc-Finger Protein Y-Linked). It turned out that this gene also does not determine sex because it is not expressed in the mouse gonads. In addition, it was observed that the male patients with karyotype 46, XX developed male traits despite the absence of the ZFY gene (Palmer 1989).

Patients described by Palmer and colleagues (four men with karyotype 46, XX) had in their genome a small, 35,000 base pair, Y chromosome-specific region [19]. This Y chromosome region was isolated, divided into fragments and compared with $\mathrm{Y}$ chromosome fragments of other mammals in Southern blotting analysis. It turned out that there is only one conserved fragment of the $\mathrm{Y}$ chromosome in mammals, which also does not show much variation between species. Thus, it was assumed that this fragment of the $\mathrm{Y}$ chromosome must contain the sex-determining gene. Sequencing of this fragment indicated only one Open Reading 
Frame (ORF) coding for the gene consisting of a single exon. This gene was called "sex determining region on the Y chromosome" (SRY in humans and Sry in mice) (Figure 1) [20,21]. RT-PCR gene expression analysis showed that the Sry gene is expressed in developing gonads of XY mice at embryonic day 11.5, just before the first signs of testicular sexual differentiation [20]. The final evidence confirming the determination of male sex by the Sry gene was provided through the study of XX transgenic mice into which the Sry transgene was introduced. These individuals, despite having the female karyotype XX, developed into typical males with normally developed testes (sex reversal), but they were sterile due to the lack of Y chromosome, which, as it turned out, also contains genes responsible for the proper course of spermatogenesis [22]. These studies proved that the Sry gene is both necessary and sufficient to determine male sex. In addition, it was shown that the Sry gene is present only in marsupials and placental mammals, i.e. in all mammals except monotremes [23,24].

\section{Studies on The Male Sex Determination Pathway}

Identification of the main function of the SRY gene was, undoubtedly, next to the discovery of the sex chromosomes, the most important discovery in the study of sex determination. However, the development of the testis, an organ with a complicated structure, had to, certainly, be controlled by several different genes besides the Sry gene, which probably just initiates subsequent changes during testis development. Further research revealed these additional genes involved in the control of gonadal development. New genes involved in sex determination have been discovered mainly owing to patients with impaired sexual development. In 1994, the cases of children with campomelic dysplasia were described, which is one of the syndromes of skeletal development disorders that may coexist with abnormal sex determination and female sexual characteristics in the fetuses with male karyotype 46, XY (feminization) [25]. In these cases, SOX9 (SRY-box transcription factor 9) gene appeared to be mutated. It turned out that the SOX9 gene is involved in bone development and sex determination. Subsequent studies have shown that the Sox9 gene is key for a male determination as it is expressed in developing testes, and specifically in future Sertoli cells in all vertebrates, examined so far. Moreover, switching off Sox 9 expression leads to a complete reversal of male to female sex [26-29]. In contrast, increased expression of Sox9 in XX mice causes their gonads to develop into testes. Thus, this gene proved necessary and sufficient to induce the development of male gonads. In mammals, $S R Y$ directly increases the expression of the Sox9 gene, and Sry and Sox 9 are two genes occupying a key place in the cascade of genes responsible for male sex determination. Sry, present only in males, is a type of inducer triggering the expression of Sox9, which then triggers the expression of several genes involved in the development of male gonads (Figure 2). These are the fibroblast growth factor (FGF9), prostaglandin D2 synthase (Ptgds), and anti-Müllerian hormone (AMH) [30-32]. FGF9 is important for accelerating cell divisions in growing male gonads, prostaglandin D2 maintains high Sox9 expression in the developing XY gonad, and AMH leads to the loss of fallopian tubes in males. Switching off the Fgf9 or Ptgds expression in mouse gonads results in a maleto-female reversion, indicating that these genes are involved in male sex determination. For a relatively long time, the question of how the expression of the Sry gene itself is triggered had not been clarified. Now, it is known that the transcription factors such as WT1 (Wilms factor 1), SF1 (Steroidogenesis Factor 1), GATA4 (GATA-binding protein 4) and IGF1 (Insulin-Like Growth Factor 1) are important in this process (Figure 2) [33].

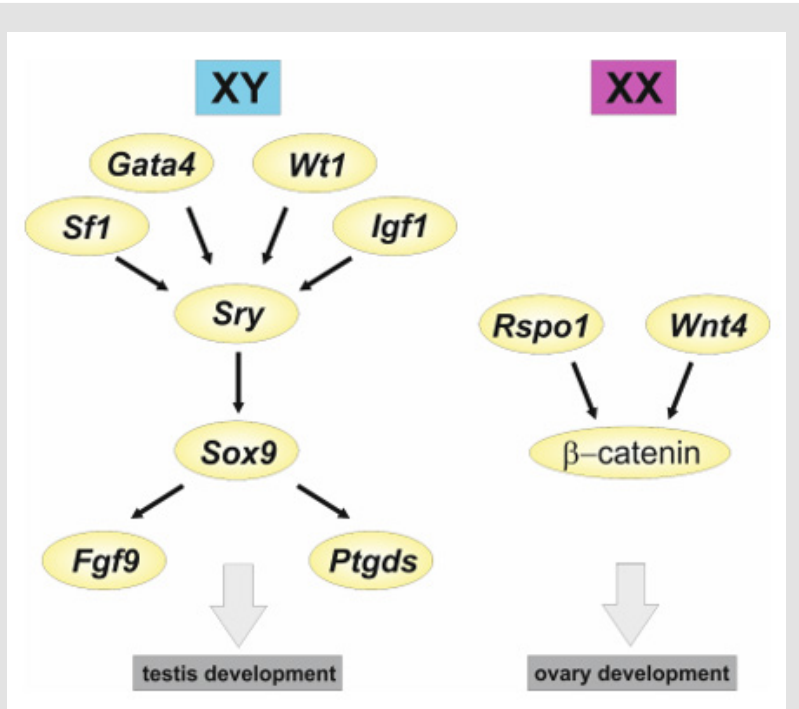

Figure 2: A simplified model of the interactions between the principal genes in the mouse sex determination. In XY gonads, the expression of Sf1, Gata4, Wt1, and Igf1 triggers the expression of Sry, which in turn upregulates the expression of Sox9. Sox 9 upregulates the expression of a series of genes, including Fgf9 and Ptgds, which drive testis development. In XX gonads, in a lack of Sry expression, there is an upregulation of Rspo1 and Wnt4 which stabilizes $\beta$-catenin leading to the expression of a series of genes driving the ovary development. 


\section{Searching for the Factors of Female Sex Determination}

Initially, ovarian development was thought to be a passive process occurring by default, in the absence of factors that trigger testes development. However, at some point, research began to show an increasing number of genes involved in ovarian development, indicating that the control of the female gonadal development is a fully active process. Initially, transcription factors DAX1 (Dosage-sensitive sex reversal, adrenal hypoplasia congenita, a critical region on the X chromosome, gene 1), FOXL2 (Forkhead box L2), and growth factor WNT4 (Wnt4 wingless-type MMTV integration site family, member 4) were the candidates for the female determination genes [34]. In goats, the mutation of the Foxl2 gene led to a female-to-male reversal, which indicated the involvement of Foxl2 in a female determination in this species [35]. In mice, on the other hand, disabling Foxl2 expression did not result in complete sex reversal, but disrupted ovarian development and caused testis-specific structures to appear in murine neonatal ovaries. This, in turn, suggested some involvement of Foxl2 in maintaining ovarian structure [36].

On the other hand, duplications of the DAX1 and WNT4 genes have been reported in humans, leading to a male-to-female reversion [37,38], indicating that in humans these genes are involved in female sex determination. Disabling Dax1 expression in mice did not result in sex reversal, but only the sterility of mutants, while disabling Wnt4 expression resulted only in a partial reversal of female to male sex, indicating that there are certainly interspecies differences in the sex determination cascades and that this process is guided by the cascade of gene expression undergoing rapid changes during evolution $[39,40]$.

An extremely important event in the studies of female determination was a case of an Italian family described in 2006 whose members had hyperkeratosis as well as male infertility (Figure 1). Genetic studies have shown that these men had a typical female genotype, i.e. 46, XX without the SRYgene [41]. This indicated that, probably, a certain gene determining female sex was mutated here, and that this mutation disrupted ovarian development and caused its development into testes (total sex reversal, called XX testicular DSD - a disorder of sex development). Genetic analysis indicated a mutation in the RSPO1 gene coding for R-spondin 1 growth factor. This was the first human case in which a single gene mutation resulted in a complete female-to-male reversal. The Rspo1 gene was found to be expressed in the differentiating ovaries of mice at an early stage of development, which confirmed the role of this gene in the control of the development of female gonads [42]. However, the inactivation of this gene in mice led only to a partial female-to-male reversal [42]. R-spondin 1 together with the WNT4 factor bind to the membrane receptors, which results in the stabilization of $\beta$-catenin, which in turn protects against its degradation in the cell cytoplasm (Figure 2). As a result, $\beta$-catenin goes to the cell nucleus, where it acts as a regulator of gene expression. It silences the expression of genes involved in the development of male gonads and thereby causes the development of female gonads [34]. This pathway plays a central role in the determination of the female sex not only in mammals but also in birds and possibly also in other vertebrates $[43,44]$. The concept developed on the basis of many experiments that had taken place in the last three decades shows that sex determination, occurring in developing gonads, is based on the complex interactions between many genes. In mammals, the Sry gene product, which is present only in the genetic males (XY), increases the expression of the Sox 9 gene, and high expression of the latter gene is maintained by FGF9 and prostaglandin D2. Both these factors simultaneously inhibit the expression of female determination genes Rspo1 and Wnt4, and as a result, the gonad differentiates into testes [45].

In contrast, in the genetic females (XX), in the absence of the Sry gene, Sox 9 achieves a low level of expression, whereby the expression of the female determination genes Rspo1 and Wnt4 is not sufficiently inhibited. This, in turn, leads to an increase in the level of $\beta$-catenin in the cytoplasm, which in turn triggers gonad differentiation into the ovaries [34]. Thus, there are two antagonistically interacting pathways for sex determination, male and female $[34,45]$. The fate of gonad development is determined by the predominance of the male or female pathway of gene expression.

\section{The Role of Hormones in Sex Determination}

Another important issue of sex determination is the role of factors creating secondary sex characteristics. The ancients were already aware of the role of the testes in the formation of male sex features. They knew that the castration led to the loss of these qualities. The first documented scientific attempt to explain the role of gonads in sexual development dates back to 1849 when the German physiologist and zoologist Arnold Berthold castrated four roosters and re-implanted the testicles into two of them [46]. Roosters with implanted testes behaved, in contrast to the castrates, like the typical males, they crowed, fought with each other and showed interest in females. Forty years later, in 1889, French physiologist and neurologist Charles Brown-Séquard injected himself with a mixture of sperm, blood, and fluid obtained from the testes of dogs and guinea pigs [47]. He maintained that this procedure rejuvenated him and extended his life. It was probably a placebo effect because the method of aqueous extraction he used eliminated hydrophobic androgens that could have some beneficial effect [48].

The first valuable evidence for the role of hormones in sexual development was provided by the observations of bovine fetuses, commonly known as freemartins [49,50]. Freemartinism is a phenomenon of masculinization of the reproductive system in a female fetus in twin pregnancy with an associated male fetus. Because the blood of both fetuses is mixed it results in normally developing male individual and the female one, masculinized, with fallopian tubes atrophy and ovarian development disorders. On this basis, it was concluded that certain hormones derived from the male fetuses cause masculinization of the female ones. 
In 1929, American physiologists T.F. Gallagher and Fred C. Koch injected castrated roosters (so-called capons) with bull testicles extract that restored the rooster behavior, such as crowing, in the capons [51]. This indicated that the male gonads from bulls produce a factor, responsible for the male traits, which is also active in birds. In 1935, a Swiss group of endocrinologists isolated $10 \mathrm{mg}$ of hormone from the bull testes, which was called testosterone (Figure 1) [52]. In the same year the first synthetic testosterone was produced [53]. Some disorders in humans help explain the role of hormones in the formation of secondary sexual characteristics. For example, patients with congenital adrenal hyperplasia have an overproduction of androgens, which in individuals with the female karyotype 46, XX can lead to the development of male secondary sexual characteristics (masculinization). In contrast, patients with karyotype 46, XY and Partial Androgen Insensitivity (PAIS), despite androgen production, show abnormalities in genital development, which demonstrates the role of androgens in the differentiation of male genitals [54]. The possibility of development features of the opposite sex in the reproductive system is due to the bipotential nature of the genital primordia called the genital ridges. Initially, the genital primordia, called the Müllerian ducts and Wolffian ducts, appear in fetuses of both genetic sexes. During the development of the male individual, Wolffian ducts develop into the vas deferens, and Müllerian ducts disappear. In contrast, during the development of the female individual, the Müllerian ducts develop into the fallopian tubes, and the Wolffian ducts disappear.

One of the most significant achievements in studying the role of hormones in sexual development were the experiments of Alfred Jost (Figure 1). This French endocrinologist, in the 40s of the 20th century, microsurgically removed undifferentiated gonads from the rabbit early fetuses and described the impact of this surgery on further development [55]. It turned out that in the absence of gonads, reproductive tract pathways had developed in the female direction, i.e. the fallopian tubes developed from the Müllerian ducts, while Wolffian ducts disappeared. In contrast, the removal of gonads at a later stage of development did not disrupt the differentiation of the reproductive system, which showed that the developing male gonads cause masculinization of the reproductive system. Jost then implanted the developing testes into female fetuses of a rabbit. This resulted in the development of the male reproductive system, i.e. the disappearance of Müllerian ducts and the development of Wolffian ducts into the vas deferens. Another experiment consisted of implanting a testosterone propionate crystal into fetuses after gonadal removal. It turned out that testosterone caused the development of the vas deferens (from Wolffian ducts), and male genitalia but did not inhibit the development of the fallopian tubes [56]. Jost concluded that testosterone produced in the testes is responsible for the development of the male reproductive system, vas deferens, and male genitals, while some additional hypothetical substance, also produced in the fetal testes, inhibits the development of the fallopian tubes (from Müllerian ducts). This substance was called MIF (Müllerian-inhibiting factor), but it took many years to discover its identity. It was in the 1970s when the French endocrinologist Nathalie Josso isolated a protein that was called Anti-Müllerian hormone (AMH) (Figure 1) [57]. Later, it turned out that the male determination gene-Sox 9 directly activates the expression of the AMH gene in the testes, whose product, the AMH hormone, diffuses into the neighboring tissues and causes apoptosis (programmed cell death) in the Müllerian ducts [58]. This prevents the development of the female reproductive system in males.

To sum up, two hormones are most important for the development of male sex characteristics: the first is the testosterone synthesized through the cooperation of fetal Leydig cells and fetal Sertoli cells, and the second is the AMH secreted by fetal Sertoli cells [59]. However, hormonal control of the development of secondary sexual characteristics is more complicated. Already in the 1960s, it was found that testosterone secreted by the testes is transformed in the target organs into a very active androgen called the Dihydrotestosterone (DHT), which is primarily responsible for the development of the penis and scrotum [60]. Recent studies shed new light on the understanding of sexual development, indicating that not only gonads but other androgen sources such as the placenta, liver, and adrenal cortex are important for the development of male sex characteristics [61].

\section{Sex Determination - Environmental Factors or Genes?}

In the 1960s, scientific evidence began showing that the environmental factors are involved in sex determination. However, this only applied to certain species, which indicated that in different species sex is determined by two mechanisms: the information stored in the genes or the effect of the environmental factors. Madeline Charnier from the University of Dakar in 1966 described the first case of Temperature Sex Determination (TSD). She showed that in the progeny of red-headed agama (Agama agama) the ratio of males to females (sex ratio) depends on the temperature at which the eggs are incubated [62]. In 1967, Susumo Ohno published a book called Sex Chromosomes and Sex-Linked Genes, in which he summarized knowledge on sex determination in various species. The author postulated that sex is genetically determined and that the reports of the effects of temperature on sex ratio should be considered only as a disorder of this process [63]. This point of view contributed to the slowing down of the research on the temperature sex determination. In 1971 and 1972, a French researcher from the University of Paris, Claude Pieau, published the results of the studies on the effect of temperature on the sex of Greek turtle (Testudo graeca), and European pond turtle (Emys orbicularis) (Figure 1) [64,65]. In the Greek turtle, the eggs incubated at a lower temperature $\left(25-30^{\circ} \mathrm{C}\right)$ almost exclusively developed to males, and at a higher temperature $\left(31-35^{\circ} \mathrm{C}\right)$ almost exclusively to females. Similarly, in the European pond turtle, incubation below $28^{\circ} \mathrm{C}$ induced males hatchling and above $29^{\circ} \mathrm{C}$ females, while both sexes 
hatched at an intermediate temperature. This was the first well documented and published, report of temperature determination in certain species.

Although it was the Pieau who pointed out that there are two types of sex determination: the genetic sex determination, in most species and the temperature sex determination in some species, it was the Charnier (1966) who discovered the temperature sex determination. The Pieau also pointed out that there is a specific, narrow time window in the fetal development of turtles, during which the temperature can determine sex. Further studies revealed the existence of the temperature sex determination in many different reptiles. The well-documented example is the American alligator (Alligator mississippiensis) in which the lower and higher temperature determines the female sex, and the intermediate temperature determines the male sex [66]. For many years it was not known how the temperature affects sex. Only the use of the advanced methods of gene expression analysis showed that, in developing gonads of red-eared turtle (Trachemys scripta), the temperature affects the expression of the gene encoding KDM6B histone demethylase [67]. This demethylase removes the methyl groups (-CH3) from the histone, thus locally affecting the expression of genes contained in the area of demethylated DNA. In the red-eared turtle, the KDM6B demethylase is expressed at a lower temperature and triggers the expression of the Dmrt1 gene responsible for the development of male gonads.

In 1995, a group from the University of Austin in Texas, showed that the Polychlorinated Biphenyls (PCBs) polluted water causes turtles and other aquatic reptiles to suffer sexual development disorders [68]. Thus, it has been shown that there are chemical compounds, including pollutants, that affect sexual development and led to the disorders of sex determination, such as total sex reversal or intersex features. These observations initiated largescale studies on the effects of various pollutants and chemicals, such as contraceptive hormones, which enter the environment with urine, on sex differentiation and gonads development.

\section{Conclusion}

Sex differences have puzzled humanity for a very long time in both scientific and social contexts. A thorough understanding of the mechanisms determining sexual development has been achieved through the use of advanced scientific techniques developed in the 20th century. However, surprisingly, the network of genes that control sex determination is still incomplete, and relatively poorly understood. Further research is likely to find novel genes involved in gonadal development and to show the complexity of the mechanisms controlling sexual development. It appears that the cascade of events leading to the sex determination is much more complicated than originally imagined. In addition, in many cases of human sex disorders, their source remains unknown, indicating that the research on the genes involved in gonadal development has a long way to go.

\section{Acknowledgement}

We acknowledge the following grants: Polish Ministry of National Defense (MON) project “Kościuszko" no: 508/2017/DA to JZK, and Polish National Science Centre (NCN) DEC-2014/15/B/ NZ3/02316 to RPP.

\section{References}

1. Lesky E (1951) Die The generation and inheritance teachings of antiquity and their aftermath. Academy of Sciences and Literature.

2. Peck AL (1942) Aristotle Generation of Animals. Harvard University Press.

3. Mittwoch U (2000) Three thousand years of questioning sex determination. Cytogenetic Cell Genet 91: 186-191.

4. Düsing C (1884) The regulation of the sex ratio in the multiplication of humans, animals and plants. Jenaische Zeitschrift für Naturwiss 16: 428464.

5. Waldayer HW (1888) About karyokinesis and its relationship to fertilization processes. microscopic anatomy and development mechanics 32: 1-122.

6. Henking H (1891) Spermatogenesis and its relationship to development in Pyrrhocoris apterus L. Scientific Zool51: 685-736.

7. Schwartz J (2009) In Pursuit of the Gene: From Darwin to DNA. Harvard University Press.

8. McClung CE (1902) The accessory chromosome-sex determinant? Biological Bulletin 3: 43-84.

9. Wilson E (1905) The chromosomes in relation to the determination of sex in insects. Science 22(564): 500-502.

10. Stevens NM (1905) Studies in spermatogenesis with especial reference to the accessory chromosome. Forgotten Books.

11. Richardson S (2013) Sex Itself: The Search for Male and Female in the Human Genome. University of Chicago Press.

12. Crow EW, Crow JF (2002) 100 Years Ago: walter sutton and the chromosome theory of heredity. Genetics 160(1): 1-4.

13. Morgan TH (1910) Chromosomes and heredity. Am Nat 44(524): 449496.

14. Morgan TH (1910) Sex Limited Inheritance in Drosophila. Science 32: 120-122.

15. Ford CE, Hamerton JL (1956) The chromosomes of man. Nature 178: 1020-1023.

16. Jacobs PA, Strong JA (1959) A case of human intersexuality having a possible XXY sex-determining mechanism. Nature 183: 302-303.

17. Ford CE, Jones KW, Polani P, de Almeida JC, Briggs JH (1959) A sexchromosome anomaly in a case of gonadal dysgenesis (Turner's syndrome). Lancet 273(7075): 711-713.

18. Jacobs PA, Ross A (1966) Structural abnormalities of the Y chromosome in man. Nature 210: 352-354.

19. Palmer MS, Sinclair AH, Berta P, Ellis NA, Goodfellow PN, et al. (1989) Genetic evidence that ZFY is not the testis-determining factor. Nature 342(6252): 937-939.

20. Gubbay J, Collignon J, Koopman P, Capel B, Economou A, et al. (1990) A gene mapping to the sex-determining region of the mouse $Y$ chromosome is a member of a novel family of embryonically expressed genes. Nature 346: $245-250$

21. Sinclair AH, Berta P, Palmer MS, Hawkins JR, Griffiths BL, et al. (1990) A gene from the human sex-determining region encodes a protein with homology to a conserved DNA binding motif. Nature 346: 240-244. 
22. Koopman P, Gubbay J, Vivian N, Goodfellow P, Lovell-Badge R (1991) Male development of chromosomally female mice transgenic for Sry. Nature 351(6322): 117-121.

23. Foster JW, Brennan FE, Hampikian GK, Goodfellow PN, Sinclair AH, et al. (1992) Evolution of sex determination and the Y chromosome: SRYrelated sequences in marsupials. Nature 35: 531-533.

24. Wallis MC, Waters PD, Delbridge ML, Kirby PJ, Pask AJ, et al. (2007) Sex determination in platypus and echidna: autosomal location of SOX3 confirms the absence of SRY from monotremes. Chromosom Res 15(8): 949-959.

25. Foster JW, Dominguez Steglich MA, Guioli S, Kwok C, Weller PA, et al. (1994) Campomelic dysplasia and autosomal sex reversal caused by mutations in an SRY-related gene. Nature 372: 525-530.

26. Bishop CE, Whitworth DJ, Qin Y, Agoulnik AI, Agoulnik IU, et al. (2000) A transgenic insertion upstream of Sox 9 is associated with dominant $\mathrm{XX}$ sex reversal in the mouse. Nat Genet 26(4): 490-494.

27. Chaboissier MC, Kobayashi A, Vidal VIP, Lützkendorf S, van de Kant HJG, et al. (2004) Functional analysis of Sox8 and Sox9 during sex determination in the mouse. Development 131(9): 1891-1901.

28. Huang B, Wang S, Ning Y, Lamb AN, Bartley J (1999) Autosomal XX sex reversal caused by duplication of SOX9. Am J Med Genet 87(4): 349-353.

29. Vidal VP, Chaboissier MC, De Rooij DG, Schedl A (2001) Sox9 induces testis development in XX transgenic mice. Nat Genet 28: 216-217.

30. Arango N, Lovell-Badge R, Behringer R (1999) Targeted mutagenesis of the endogenous mouse Mis gene promoter: in vivo definition of genetic pathways of vertebrate sexual development. Cell 99(4): 409-419.

31. Kim Y, Kobayashi A, Sekido R, DiNapoli L, Brennan J, et al. (2006) Fgf9 and Wnt4 act as antagonistic signals to regulate mammalian sex determination. PLoS Biol 4(6): 1000-1009.

32. Wilhelm D, Palmer S, Koopman P (2007) Sex determination and gonadal development in mammals. Physiol Rev 87(1): 1-28.

33. Larney C, Bailey TL, Koopman P (2014) Switching on sex: transcriptional regulation of the testis-determining gene Sry. Development 141(11) 2195-2205.

34. Piprek RP (2009) Molecular mechanisms underlying female sex determination - antagonism between female and male pathway. Fol Biol 57(3-4): 105-113.

35. Pailhoux E, Vigier B, Vaiman D, Servel N, Chaffaux S, et al. (2002) Ontogenesis of female-to-male sex-reversal in XX polled goats. Dev Dyn 224(1): 39-50.

36. Uhlenhaut NH, Jakob S, Anlag K, Eisenberger T, Sekido R, Kress J, et al. (2009) Somatic sex reprogramming of adult ovaries to testes by FOXL2 ablation. Cell 139(6): 1130-1142.

37. Jordan BK, Mohammed M, Ching ST, Délot E, Chen XN, et al. (2001) Up-regulation of WNT-4 signaling and dosage-sensitive sex reversal in humans. Am J Hum Genet 68(5): 1102-1109.

38. Jordan BK, Mohammed M, Ching ST, Délot E, Chen XN, et al. (2001) Up-regulation of WNT-4 signaling and dosage-sensitive sex reversal in humans. Am J Hum Genet 68(5): 1102-1109.

39. Yu RN, Ito M, Saunders TL, Camper SA, Jameson JL (1998) Role of Ahch in gonadal development and gametogenesis. Nat Genet 20(4): 353-357.

40. Vainio S, Heikkilä M, Kispert A, Chin N, McMahon AP (1999) Female development in mammals is regulated by Wnt-4 signalling. Nature 397(6718): 405-409.

41. Parma P, Radi O, Vidal V, Chaboissier MC, Dellambra E, et al. (2006) $\mathrm{R}$-spondin1 is essential in sex determination, skin differentiation and malignancy. Nat Genet 38(11): 1304-1309.

42. Chassot AA, Ranc F, Gregoire EP, Roepers Gajadien HL, Taketo MM, et al. (2008) Activation of beta-catenin signaling by Rspo1 controls differentiation of the mammalian ovary. Hum Mol Genet 17(9): 12641277.
43. Smith CA, Shoemaker CM, Roeszler KN, Queen J, Crews D, et al. (2008) Cloning and expression of R-Spondin 1 in different vertebrates suggests a conserved role in ovarian development. BMC Dev Biol 8: 72.

44. Piprek RP, Pecio A, Laskowska Kaszub K, Kubiak JZ, Szymura JM (2013) Sexual dimorphism of AMH, DMRT1 and RSPO1 localization in the developing gonads of six anuran species. Int J Dev Biol 57(11-12): 891895.

45. Piprek RP (2009) Genetic mechanisms underlying male sex determination in mammals. J Appl Genet 50(4): 347-360.

46. Berthold AA (1849) Transplantation der Hoden. Arch Anat Physiol Wissensch 42-46.

47. Brown-Sequard CE (1889) Note on the effects produced on man by subcutaneous injection of a liquid obtained from the testicles of animals. Lancet 137(3438): 101-107.

48. Rengachary SS, Colen C (2008) Charles-Edouard Brown-Séquard: an eccentric genius. Neurosurgery 62(4): 954-964.

49. Keller K, Tandler J (1916) About the behavior of the egg skins when the cattle are pregnant. 3: 513-526.

50. Lillie FR (1916) The theory of the free martin. Science 43(1113): 611613.

51. Gallagher TF, Koch FC (1929) The testicular hormone. J Biol Chem 84: 495-500.

52. David K, Dingemanse E, Freud J, Laqueur E (1935) Crystalline male hormone from testes (testosterone) more active than androsterone preparations from urine or cholesterol. Zeitschrift Physiologische Chemie 233: 281-293

53. Butenandt A, Hanisch G (1935) The transformation of dehydroandrosterone into androstendiol and testosterone; a method for producing testosterone from cholesterin. Hoppe-Seyler's Z Physiol Chem 237: 89-98.

54. McPhaul MJ (2002) Androgen receptor mutations and androgen insensitivity. Mol Cell Endocrinol 198(1-2): 61-67.

55. Jost PA (1948) Hormonal Control of Sex Differentiation. Biological Reviews 23(2): 201-236.

56. Jost A (1953) Problems of Fetal Endocrinology: The Gonadal and Hypophyseal Hormones. Recent Prog Horm Res 33: 117-160.

57. Josso N (1973) In vitrosynthesis of mullerian-inhibiting hormone by seminiferous tubulesisolated from the calf fetal testis. Endocrinology 93(4): 829-834

58. Roberts LM, Visser JA, Ingraham HA (2002) Involvement of a matrix metalloproteinase in MIS-induced cell death during urogenital development. Development 129(6): 1487-1496.

59. Shima Y, Miyabayashi K, Haraguchi S, Arakawa T, Otake H, et al. (2013) Contribution of Leydig and Sertoli cells to testosterone production in mouse fetal testes. Mol Endocrinol 27(1): 63-73.

60. Wilson JD, Walker JD (1969) The conversion of testosterone to $5 \alpha$-androstan-17 $\beta$-ol-3-one (dihydrotestosterone) by skin slices of man. J Clin Invest 48(2): 371-379.

61. O Shaughnessy PJ, Antignac JP, Le Bizec B, Morvan ML, Svechnikov $\mathrm{K}$, et al. (2019) Alternative (backdoor) androgen production and masculinization in the human fetus. PLoS Biol 17(2).

62. Charnier M (1966) Action of Temperature on Sex Ratio in the Agama (Agamidae: Lacertilia) embryo. Records of Meetings of the Society of Biology of West Africa 160(3): 620-622.

63. Ohno S (1967) Sex Chromosomes and Sex-Linked Genes. Berlin Springer Verlag.

64. Pieau C (1971) Sur la Proportion Sexuelle chez les Embryons de Deux Cheloniens (Testudo graeca L. et Emys orbicularis L.) Issus d'Oeufs 
Incubes Artificiellement [The Sexual Proportion of Embryos of Two Chelonians from Artificial Incubation of Eggs]. Comptes Rendus Academie des Sciences, Paris Academy of Sciences Reports, Paris 272 3071-3074.

65. Pieau C (1972) Effects of Temperature on the Development of Glands in Embryo Genitals of Two Chelonians, Emys orbicularis and Testudo graeca. Comptes Rendus Academie des Sciences, Paris [Academy of Sciences Reports, Paris] 274(5): 719-722.

\section{ISSN: 2574-1241}

DOI: $10.26717 /$ BJSTR.2020.25.004194

Rafal P Piprek. Biomed J Sci \& Tech Res

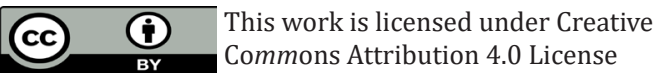

Submission Link: https://biomedres.us/submit-manuscript.php
66. Ferguson WJ, Joanen T (1982) Temperature of egg incubation determines sex in Alligator mississippiensis. Nature 296: 850-853.

67. Ge C, Ye J, Weber C, Sun W, Zhang H, et al. (2018) The histone demethylase KDM6B regulates temperature-dependent sex determination in a turtle species. Science 360(6389): 645-648.

68. Crews D, Bergeron J, McLachlan J (1995) The role of estrogen in turtle sex determination and the effect of PCBs. Environ Health Perspect 103(suppl 7): 73-77.

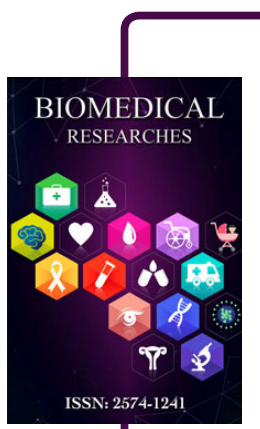

Assets of Publishing with us

- Global archiving of articles

- Immediate, unrestricted online access

- Rigorous Peer Review Process

- Authors Retain Copyrights

- Unique DOI for all articles

https://biomedres.us/ 